SPECIAL ISSUE ARTICLE

\title{
A century of victimhood: Antecedents and current impacts of perceived suffering in World War I across Europe
}

Pierre Bouchat*, Laurent Licata*, Valérie Rosoux†, Christian Allesch $¥$, Heinrich Ammerer§, Inna Bovinaף, Susanne Bruckmüller\#, Rosa Cabecinhas||, Xenia Chryssochoou**, J. Christopher Cohrs††, István Csertőł‡, Sylvain Delouvée§§, Federica Duranteף币, Andreea Ernst-Vintila\#\#, Christine Flassbeck***, Denis Hilton†††, Chantal Kesteloot¥¥¥,

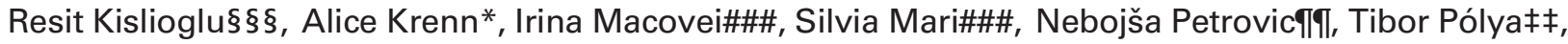

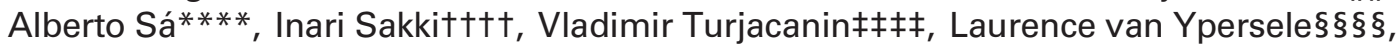
Chiara Volpatođা, Michal Bilewiczđ|TाT, Olivier Klein*

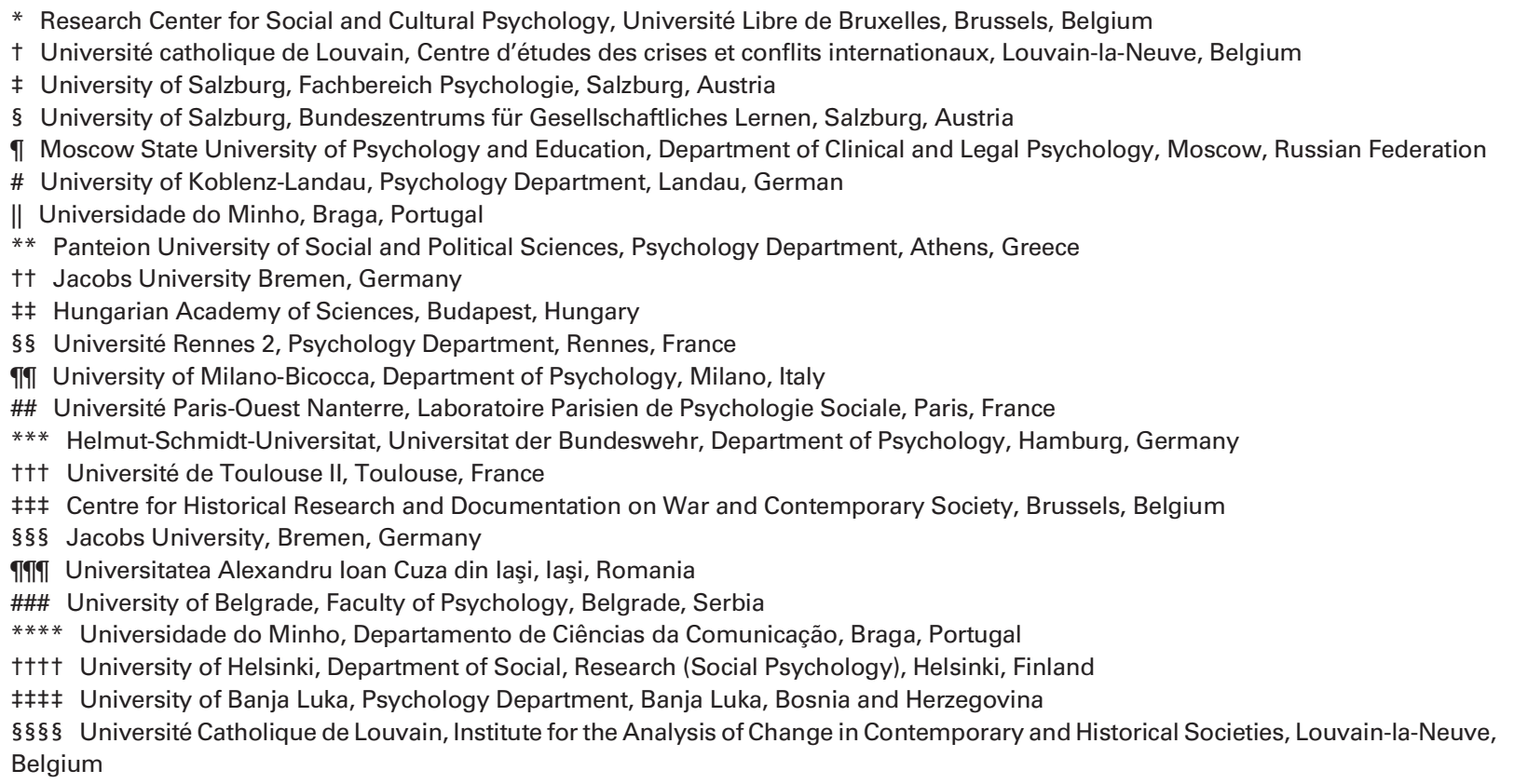

१ाभा Center for Research on Prejudice, Faculty of Psychology, Warsaw University, Warsaw, Poland

Correspondence Pierre Bouchat, Université libre de Bruxelles, Service de Psychologie sociale, Brussels, Belgium. E-mail: pierre.bouchat@ulb.ac.be

Received: 22 December 2015 Accepted: 12 July 2016

http://dx.doi.org/10.1002/ejsp.2232

Keywords: collective memory, pacifism, collective victimhood, WWI

\begin{abstract}
The present study addresses antecedents and consequences of collective victimhood in the context of World War I (WWI) across 15 European nations $(N=2423$ social science students). Using multilevel analysis, we find evidence that collective victimhood is still present a hundred years after the onset of the war and can be predicted by WWI-related objective indicators of victimization at national and family levels. This suggests that collective victimhood is partly grounded in the actual experience of WWI. In addition, we show that sense of collective victimhood positively predicts acknowledgment of the suffering inflicted by one's nation on other countries during WWI. This is consistent with a social representation of WWI as involving a vast massacre in which nations were both victim and perpetrator. Finally, we find that objective indicators of victimization predict pacifism in divergent ways, with an indicator at the national level associated with more pacifist attitudes and an indicator at the family level being associated with less pacifist attitudes. This finding suggests that war-torn societies may have developed social representations favouring peaceful coexistence whereas, at the family level, victimization may still foster retaliatory tendencies.
\end{abstract}

"This war, like the next war, is a war to end war"

David Lloyd George (cited by Lucas, 1932, p. 296)

Self-perceived collective victimhood can be defined as "a mindset shared by group members that results from a perceived intentional harm with severe and lasting consequences inflicted on a collective by another group or groups, a harm that is viewed as undeserved, unjust and immoral and one that the group was not able to prevent" (Bar-Tal, Chernyak-Hai, Schori, \& Gundar, 
2009, p. 238). Vollhardt (2012) further notes that "ingroup identification can result in an intense perception of collective victimhood even if the harm has not been experienced personally, but only by other members of one's group; and even when the victimization did not occur in a person's lifetime, but centuries ago" (p. 2).

Social psychologists have been primarily preoccupied with the question of how this sense of collective victimhood can influence group members' current social identity and their attitudes and behaviours towards relevant out-groups (e.g., Bar-Tal \& Antebi, 1992; Noor, Shnabel, Halabi, \& Nadler, 2012; Rimé, Bouchat, Klein, $\delta$ Licata, 2015). In keeping with a Lewinian perspective, the question of whether this sense of victimhood maps onto objective facts has not been considered of primary interest. Social psychologists do not deny the reality of the events that initiated this sense of victimhood, but it is the phenomenology of victimhood that has preoccupied the field: The interest of social psychologists has delved on subjective experience of shared victimhood rather than on "objective" victimization, which is the province of historians.

More generally, in appraising victimhood, social psychologists have considered that group members may sometimes greatly suffer without an inevitable sense of collective victimhood whereas other, possibly less severe, harms may lead to a strong sense of victimhood. This is because some victimizing events may be more easily articulated in narratives depicting the group's history than others (Hammack, 2009; László, 2013). To take an example, the notion that, during the First World War, (Belgian) Flemish soldiers died in "Flanders' fields" because they did not understand the orders of their French speaking superiors has featured prominently in collective memory because it fits the nationalist agenda of the Flemish movement (see Klein, Licata, Van der Linden, Mercy, \& Luminet, 2012), which aimed at more autonomy from the (then) French speaking elite. Yet, the role this factor played in Flemish fatalities during the First World War has not been substantiated historically and, compared to other countries, Belgium experienced very few military fatalities in World War I (De Vos \& Keymeulen, 1989). According to such a phenomenological perspective, there may actually be little relation between the "objective" indicators of victimization (e.g., number of fatalities) associated with the history of a specific group and "subjective" victimization given that the narratives that shape collective memory can easily distort reality (e.g., Baumeister \& Hastings, 1997). This does not mean that such social representations are independent of reality but that the connection between victimhood and social reality may be largely indirect or metaphorical (e.g., the iconic Flemish soldier as representative of the oppressed Flemish people, cf. Assman \& Conrad, 2010).

Using this perspective as a point of departure, our first goal in this paper is specifically to test whether there is a correspondence between objective indicators of past victimization across individuals and groups and subjective experiences of victimhood. Appraising the role of objective victimization in collective victimhood is often an intricate matter given that one tends to focus on a single case or socio-historical context of victimization (e.g., the Holocaust for Jews or the Israeli-Palestinian conflict). A limitation of such an approach is that it only affords to investigate intragroup variations in victimhood. Yet, if victimization is a socially constructed experience (i.e., embedded in social representations, cf. Elcheroth, 2006), appraising the experience of several distinct groups is necessary.

\section{Victimization in World War I}

World War I, the historical context considered in this article, constitutes an ideal setting for appraising this question. A cross-cultural survey conducted in 24 societies (Liu et al., 2005, see also Hilton \& Liu, 2008) showed that World War I (WWI) was nominated across the globe as the second most important event in World History, after World War II (WWII; see also Bobowik et al., 2014). While its scale was global, this conflict has particularly affected the European continent. WWI broke out in June 1914 and the most important battles took place in Europe. In November 1918, at the end of the war, the Old Continent was devastated. To appraise its impact, consider that $50 \%$ of the adult male population of the nations involved in the war enrolled in an army and that of these, half were killed, wounded or made prisoners (Winter, 2004). The toll of the war included vast destructions and political instability in addition to the millions of dead and wounded. This led a range of specialists (e.g., Morin, 1987) to characterize the First World War as a "Suicide of Europe".

Yet, the countries involved in this conflict have experienced varying levels of damage and fatalities. Are group members sensitive to these differences? Do the most afflicted countries perceive themselves as having been more victimized during WWI than those that were less affected? Answering these questions allows us to examine the persistence of collective victimhood long after perpetrators and victims are deceased in people who have not even had direct contact with them. Thus, it is a strong test of the persistence of a sense of collective victimhood across time. At a broader level, addressing this issue allows us to contribute to a core debate in memory studies (cf. Ricoeur, 2004): What is the relation between history and memory, that is, between the actual events that took place in the past and contemporary representations of these events?

In this paper, we focus on an objective indicator of victimization: the number of fatalities per country. While victimization can take many forms, loss of lives is certainly one of the most severe and uncontroversial, especially in the context of an armed conflict. With respect to WWI, the number of fatalities per country, although still subject to debate, can be established with a satisfying degree of accuracy (e.g., Audoin-Rouzeau $\delta$ Becker, 2000; Overmans, 2004). These rates 
constitute an objective indicator of victimization at the societal level and vary widely between European countries.

Casualty rates constitute one of the indicators that can be considered at several levels of analysis. While at the societal level, loss of lives is assessed in terms of death toll by countries, at an individual level, the loss of lives can be appraised by variables such as the presence of a victim of the conflict in the descendant's family. In line with this reasoning, we shall examine whether these two variables - the death toll by country (objective indicator of victimization at the societal level) and the presence of a victim of the conflict within the descendant's family (objective indicator of victimization at the individual level)—predict, across a century, a sense of collective victimhood specific to the First World War.

Over and above these "objective" variables, we seek to examine psychological predictors of sense of collective victimhood as well, and we focus especially on national identification: Indeed, a sense of collective victimhood is presumed on self-categorization within the in-group. Consistent with this view, past research has identified a positive association between group identification and perceived group victimization (e.g., Rimé et al., 2015).

This leads us to formulate the following hypotheses:

1. The level of WWI-related sense of collective victimhood should be predicted positively by the casualty rate at the country level (la) and by the presence of family members involved in the war (lb).

2. The level of national identification should predict sense of collective victimhood positively.

We now turn to the impact of this sense of collective victimhood on two critical outcomes: the acknowledgment of suffering inflicted on out-groups and the endorsement of pacifist attitudes.

\section{Acknowledgment of Inflicted Suffering}

Collective victimization is often only one face of the coin in many armed conflicts. In the case of WWI, nations were not only victims of war, they were also agents of war, victimizers. Acknowledgment of the victimization inflicted on other groups can be crucial to the establishment of harmonious relations after a violent conflict (Noor, Brown, Gonzalez, Manzi, \& Lewis, 2008; Vollhardt, Mazur, \& Lemahieu, 2014): Indeed, victims of mass violence want their suffering to be acknowledged by relevant out-groups, in particular by the perpetrators. This is often necessary for reconciliation (see Barkan, 2000; Brooks, 1999; Lind, 2008) and may actually manifest the group's, or nation's, willingness to engage in more peaceful relations (Čehajić-Clancy, Effron, Halperin, Liberman, \& Ross, 2011; Rosoux, 2004). Hence, addressing the predictors of such acknowledgment is far from a trivial question. In the present case, as in many, groups are both victims and perpetrators. Which relation can we expect between collective victimhood and acknowledgment of inflicted suffering?

While acknowledgment of ingroup responsibility for having inflicted harm on other groups is an antecedent of collective guilt (cf. Branscombe \& Doosje, 2004 for an overview), it is not equivalent to this sentiment. Indeed, while people may acknowledge that their group has harmed another group, they may not necessarily view these actions as illegitimate, accept moral responsibility for these actions (if they construe them as wrongdoings) and experience the resulting feeling of collective guilt (Wohl, Branscombe, \& Klar, 2006).

Victimhood presupposes a clear distinction between "perpetrators" and "victims". While being labelled a perpetrator may be threatening to social identity (e.g., Doosje, Branscombe, Spears, \& Manstead, 1998; Klein, Licata, \& Pierucci, 2011), the victim status is more ambiguous. On the one hand, being a victimized in-group may induce shame or humiliation (Rice \& Benson, 2005; Volkan, 2001, cited by Vollhardt, 2010). On the other hand, in the context of a comparison with the perpetrators, the victim has the moral high ground (Baumeister, Exline, \& Sommer, 1998)—which may partially explain why many groups seek recognition of their victim status (Chaumont, 1997; Todorov, 1995). This leads us to the following additional hypotheses:

3. If an opposition between perpetrator and victim status is firmly entrenched in Europeans' minds, the acknowledgment of suffering inflicted on other groups should be a negative function of collective victimhood.

4. Contemporary Europeans should be more likely to acknowledge the harm inflicted on other groups to the extent that they weakly identify with their national group (because this harm threatens their social identity: Doosje et al., 1998)

Hypothesis 3 is based on the assumption that the salience of the opposition between victim and perpetrator status is a function of the symbolic benefits that victim status accrues to people's social identity. If this is the case, people who strongly identify with their group should be more sensitive to these benefits and therefore be more likely to consider victim and perpetrator status as distinct and non-overlapping categories. Hence:

5. The negative relation between victimhood and acknowledgment of suffering inflicted on other groups postulated under Hyp. 3 should be stronger among people who identify strongly with their group.

\section{Effects of Collective Victimhood on Pacifism}

While few studies have considered the antecedents of the sense of collective victimhood, a significant amount of research has sought to investigate its effects, adopting mainly the "meso" level (i.e., intergroup) of analysis in 
Vollhardt's terminology. In this vein, Bar-Tal and colleagues have shown that victimizing beliefs can influence almost all aspects of the lives of the members of a society (see Bar-Tal et al., 2009 for a review). The sense of collective victimhood can have consequences at many levels. As such, it can affect the way group members see the world (e.g., Bieber, 2002; Noor et al., 2012; Schori-Eyal, Halperin, \& Bar-Tal, 2014), process the information (e.g., Baumeister \& Hastings, 1997; Levene, 1999, cited by Vollhardt, 2012) and their emotions (e.g., Halperin, Bar-Tal, Nets-Zehngut, \& Drori, 2008; Pennekamp, Doosje, Zebel, \& Fischer, 2007; Staub, 2006).

But, to date, most studies on this topic have focused on the harmful effects of collective victimhood on intergroup relations (Vollhardt, 2010). Past victimization during an intergroup conflict was shown, among other things, to be related to a reduced willingness to acknowledge the responsibility of the ingroup for atrocities committed during a conflict (Čehajić, Brown, \& González, 2009) and a reduction of collective guilt when harmful acts are committed by members of the ingroup during a conflict (Wohl \& Branscombe, 2005). Even though a majority of studies have highlighted the negative consequences of collective victimhood, it can also exert positive effects on intergroup relations (cf. Klar, Schori-Eyal, \& Klar, 2013). For example, members of historically victimized groups may experience a high obligation to help members from other victimized groups (Warner, Wohl, \& Branscombe, 2014) or a strong reluctance to inflict harm on out-groups (Klar et al., 2013).

Finally, as we have already noted, victimization can be experienced at an individual level—when one has been directly affected by war, or in the case of WWI, when one's relatives or ancestors have been affected, or at a collective level. The effect of these two types of victimization can be distinct. In a large-scale study conducted in 14 countries recently torn by civil war, Elcheroth (2006) showed that communities with a large number of victims of civil war tend to be more favourable to humanitarian norms. This finding is explained by the existence of social representations associated with the shared threat of anomie (Durkheim, 1897/1987), that is deregulation and disintegration that may afflict societies after such a conflict. The prevention of anomie after a violent conflict can only be achieved by the implementation of shared standards that protect the community, including humanitarian law. Thus, at the collective level, victimization predicted endorsement of humanitarian law. Conversely, it appears that, at the individual level, victims of a war episode were less in favour of a legal conception of humanitarian norms than non-victimized individuals (Elcheroth, 2006). Building on just world theory (Lerner, 1998), Elcheroth suggests that victims of war may fear being singled out as victims (because "bad things happen to bad people") and may as a consequence be unfavourable to judicial responses that will officialise their status. Using multilevel analyses, this study found contrasting effects of victimhood on endorsement of lawful means ensuring a peaceful coexistence depending on whether it was measured at the individual or at the community level.

Pursuing this approach, we consider the consequences of collective victimization on a specific attitude: pacifism. Strangely, to our knowledge, research on collective victimhood, which typically focuses on war contexts, has failed to consider the impact of this experience on attitudes towards war and peace. Conversely, research on attitudes towards war and peace has also failed to investigate the impact of victimhood (for an overview, see Cohrs \& O'Dwyer, in press). Knowing if and when collective victimhood fuels positive attitudes towards peace is a question of both major theoretical and practical interest.

The choice of this variable is also motivated by the strong association between World War I and the development of a pacifist movement, especially in Europe (for an historical overview, see. Prost \& Winter, 2004). But can perceived victimization experienced in a distinct past still influence the pacifism of young adults from European countries hundred years later? And if so, in which direction? Elcheroth's findings indicate that victimization experienced at the societal level leads to more favourable attitudes toward humanitarian norms, while victimization experienced at the individual level has an opposite effect and may contribute to renewing the cycle of violence. Naturally, however, the vast difference between the contexts studied by Elcheroth and WWI may not warrant a direct transposition of these results. Yet there are reasons to believe his hypotheses may inform the present context as well.

During and after WW1, pacifism was a vast social movement whose views became part of official discourse, especially in Western European countries (Brock \& Young, 1999; Prost \& Winter, 2004). From this perspective, we expect that, if it is still influential today, the death toll per country should influence pacifist attitudes at a macro level. If we attempt to transpose Elcheroth's analysis to the European context, group-level victimhood may have fostered institutions, values and social representations that aim at preserving peaceful coexistence between European countries.

At the individual level, by contrast, earlier research (Elcheroth, 2006) suggests that victimization is unlikely to foster positive attitudes towards out-groups. On the contrary, it leads to a perception of threat (Staub $\delta$ Bar-Tal, 2003) and may also encourage retaliation towards the perpetrators of victimization (McCullough, Kurzban, \& Tabak, 2013). This should result in less pacifist attitudes. Research on the individual consequences of victimization has generally focused on first-hand victims. The present research extends this past work by examining whether vicarious experiences of victimization, experienced by family members, may exert the same effect over a 100-year period.

Finally, we address the possible impact on pacifism of our two psychological indicators: sense of collective victimhood and acknowledgment of inflicted suffering. We have suggested that acknowledging the suffering 
inflicted on other countries may be driven by a commitment to peaceful coexistence with other groups (i.e., "reconciliation"). If this is the case, acknowledgment of the suffering inflicted on other groups should be positively associated with pacifism.

This leads to the following hypotheses:

6. Levels of Pacifism should be higher in countries that experienced many fatalities during the war.

7. Levels of Pacifism should be lower among people who were affected by the war through their family members.

8. A subjective sense of WWI-related collective victimhood should be associated with less pacifist attitudes.

9. Acknowledgment of the suffering inflicted on other countries should predict more pacifist attitudes.

\section{Method}

We tested our hypotheses in the context of a large interdisciplinary online survey involving social psychologists and historians (only parts of this survey are reported here but the full questionnaire is available here: osf.io/ $3 \mathrm{dkvb})$. The survey took the form of an online questionnaire and was conducted among university students in social science, between March 2014 and July 2015.

Social science students (mostly in psychology) from 21 countries answered the questionnaire, which was presented to them in their language of education. Only 15 non-neutral countries from which reliable information on losses in the First World War were available were considered in our analyses: Austria, Belgium, Bosnia and Herzegovina, Finland, France, Germany, Greece, Hungary, Italy, Portugal, Romania, Russia, Serbia, Turkey and the United Kingdom. The sample consisted of 2423 participants (52\% women) whose average age was 23.10 years $(S D=7.64)$. The main
European belligerents of that time were represented. Completing the full questionnaire took an average of 30 min. Besides a section dedicated to demographic information, it was composed of several items/scales (see Table 1).

Sense of historical collective victimhood. To the best of our knowledge, there is no validated scale of the sense of historical collective victimhood per se. Existing scales address specific aspects of victimhood, such as competitive victimhood (Noor, Brown, \& Prentice, 2008) or inclusive/exclusive victimhood (Vollhardt, 2010). In light of that fact, the indicator of historical collective victimhood we used consists in an item adapted from a previous study by Rimé et al. (2015): “During the First World War, my country suffered from the behaviour of the enemy countries". All variables were measured on 7-point scales, ranging from 1 (= "Not at all") to 7 (= "Very strongly"), unless otherwise specified.

Inflicted sufferings to enemy countries. The acknowledgment of inflicted suffering was appraised using the following item: "During the First World War, enemy countries suffered from the behaviour of my country".

Family involvement. The objective indicator of victimization at the individual level was measured by asking participants if any member of their family had fought or died during the First World War. Participants could answer "yes", "no" or "I do not know". Although fighting a war does not entail victimization, there is a large consensus that, for most soldiers, the experience of fighting in the First World War was immensely challenging and was often a traumatic experience (Abbott, 2005; Audoin-Rouzeau \& Becker, 2000; Gallagher, 2015). We also know that the

Table 1. Sample characteristics, status during the war, death toll during WWI and WWII, historical collective victimhood, sufferings inflicted, identification to country and pacifism

\begin{tabular}{|c|c|c|c|c|c|c|c|c|c|}
\hline Country & $N$ & $\begin{array}{c}\% \\
\text { women }\end{array}$ & $\begin{array}{c}\text { Status during } \\
\text { war }\end{array}$ & $\begin{array}{l}\text { Death toll } \\
\text { WWI }\end{array}$ & $\begin{array}{l}\text { Death toll } \\
\text { WWII }\end{array}$ & $\begin{array}{l}\text { Hist. } \\
\text { vict. }\end{array}$ & $\begin{array}{l}\text { Inflict. } \\
\text { suff }\end{array}$ & $\begin{array}{l}\text { Country } \\
\text { ident. }\end{array}$ & Pacifism \\
\hline Austria & 126 & 68.3 & C & 51 & 57 & 5.26 & 5.47 & 3.65 & 5.73 \\
\hline Belgium & 281 & 65.1 & $E$ & 13.4 & 10.5 & 5.59 & 3.59 & 3.79 & 5.27 \\
\hline Bosnia and Herzegovina & 189 & 73.5 & C & 100 & 41.8 & 6.09 & 3.19 & 3.97 & 5.70 \\
\hline Finland & 180 & 52.2 & $E$ & 9 & 26.2 & 3.94 & 1.99 & 3.85 & 5.41 \\
\hline France & 99 & 78.8 & $E$ & 42.9 & 13.5 & 5.29 & 5.05 & 3.58 & 5.38 \\
\hline Germany & 134 & 30.6 & C & 33.9 & 79 & 4.90 & 5.51 & 4.08 & 5.01 \\
\hline Greece & 200 & 77.5 & $E$ & 32.3 & 70.2 & 4.57 & 3.37 & 3.56 & 5.33 \\
\hline Hungary & 161 & 52.8 & C & 31 & 63.5 & 5.76 & 4.54 & 3.84 & 5.27 \\
\hline Italy & 137 & 81.8 & $E$ & 29.6 & 10.3 & 4.86 & 4.50 & 3.11 & 5.63 \\
\hline Portugal & 81 & 58.0 & $E$ & 14.9 & 0 & 4.85 & 2.78 & 4.23 & 5.69 \\
\hline Romania & 146 & 76.0 & $E$ & 77.7 & 40.1 & 5.36 & 3.24 & 4.22 & 5.52 \\
\hline Russia & 116 & 80.2 & $E$ & 16.2 & 127 & 5.20 & 4.46 & 4.02 & 5.08 \\
\hline Serbia & 313 & 57.2 & $E$ & 166.7 & / & 5.71 & 2.36 & 3.38 & 5.57 \\
\hline Turkey & 74 & 75.7 & C & 132.6 & 0 & 5.15 & 3.41 & 3.29 & 5.64 \\
\hline United Kingdom & 63 & 31.7 & $\mathrm{E}$ & 17.9 & 9.4 & 4.67 & 4.71 & 4.44 & 4.82 \\
\hline
\end{tabular}

Note. $N$ = sample size; $\mathrm{E}=$ entente; $\mathrm{C}=$ central powers; death toll WWI = losses for 1000 citizens during WWl; death toll WWII = losses for 1000 citizens during WWII; hist. vict. = historical collective victimhood; inflict. suff = inflicted sufferings to enemy countries; country ident. = identification to the country. 
experience of former soldiers, even if they were not wounded or killed, took a great toll on their family and their entourage (Cabanes \& Piketty, 2009; Davoine \& Gaudillière, 2004). Hence, although it does not distinguish between "fighting" and "dying", this variable can be considered as an indicator of familylevel victimization. Participants may answer "yes" based on the assumption that someone in their extended family was affected by the war but without having any specific knowledge or memory. We addressed this concern by including an extra question aimed at assessing the source of their knowledge. The participants who answered "yes" to the question about family victimization were then asked to report the source of this information. ${ }^{1}$

Societal-level experience of victimization. The societal-level indicator of victimization was measured using the loss rate per 1000 citizens for each country. These data were based on Prost (2014), Riedlmayer (1993) and the Wikipedia article on World War I Casualties (.) as in the study of Paez et al. (2008). A similar indicator was developed for World War II (World War II Casualties, n.d.). ${ }^{2}$

Identification with the country. Identification with the country was measured using a modified version of the national identification scale by Roccas, Klar, and Liviatan (2006), comprising 15 items (e.g., "I love my country", "Compared to other countries, we are a very moral country"). Identification with the country was preferred to national identification in order to avoid non-comparable answers in multinational countries. The original scale by Roccas et al. (2006) is composed of two subscales: "attachment" and "glorification". Given that the two subscales were highly intercorrelated $(r=.69)$, we aggregated them $(\alpha=.88$ to .95$)$.

Pacifism. The level of pacifism of the participants was assessed using the Attitudes Toward Peace and War Scale (APWS: Bizumic et al., 2013). Although the scale includes two sub-dimensions (i.e., attitudes toward peace $\delta$ attitudes toward war), a principal component analysis showed that items loaded highly on a single factor and we therefore decided to treat the scale as unidimensional. This is quite common also for similar measures of attitudes toward war or militaristic attitudes (see, e.g., Cohrs \& Nelson, 2012). APWS consists of 16 items such as "Our country's first priority should be world peace" and "There is no conceivable justification for war". This scale has a good internal consistency ( $\alpha=.76$ to .86 depending on the sample).

\footnotetext{
${ }^{1}$ Participants were proposed to following answers: Grandfather, grandmother, parents, uncles, relatives, other (specify).

${ }^{2}$ Note that with respect to Turkey, we ran models including and not including the casualties of the Armenian Genocide. This did not affect the outcome of the analyses involving this variable. The analyses reported here include these victims.
}

\section{Results}

\section{Sense of Historical Collective Victimhood}

Mean scores ranged from $3.94(S D=1.69)$ for the Finnish sample to $6.09(S D=1.21)$ for Bosnia and Herzegovina (see Table 1). With the exception of Finland, all samples scored higher than 4.6 on the scale, suggesting the presence of a pervasive perceived historical collective victimhood. Further, $55.6 \%$ of the participants who stated having a victimized ancestor reported having learned it from one or several of their grandparents. As their grandparents were potentially in contact with the generation of the war, this additional information suggests that at least part of the students could have a specific knowledge or memory of their victimized ancestors.

The effects of objective predictors on perceived collective victimhood were appraised by using multilevel regression analysis using maximum likelihood estimation. Multilevel analyses allow taking into account the effects of variables at different levels of analysis. They provide the opportunity to assess the effects of macro-level variables in addition to the more classically used individual-level ones (Pettigrew, 2006). Analyses were run using the lme4 package of the $\mathrm{R}$ software (Bates, Mächler, Bolker, \& Walker, 2014) complemented by lmerTest (Kuznetsova, Borckhoff, $\delta$ Christensen, 2015), another package that tests the statistical significance of lme4 models.

For predictors that vary within countries, we included both a random slope and a random intercept in an initial model. Following the recommendation of Snijders and Bosker (1999), if the addition of the random slope did not improve the fit of the model at alpha $=.05$ (i.e., indicating that slopes do not vary significantly as a function of the county), we selected a simpler model with fixed slopes. When random slopes are justified, we report it but we do not discuss within-country variations in the predictive power of a given level 1 predictor. ${ }^{3}$ Indeed, the focus of this paper lies in understanding whether such variables predict specific outcomes over and above national variations rather than in explaining idiosyncratic within-country effects.

In addition, note that all continuous level 1 predictors were centred within each country prior to analyses. This is important for interpretation of the intercept and slope parameters in a multilevel analysis (Enders \& Tofighi, 2007). Thanks to this strategy, the latter are not influenced by between country variations in the parameter. Finally, note that cases with missing values were excluded list wise for each individual model being tested. Hence, the number of observations may differ across analyses.

Results are reported in Table 2 . The deviance parameter (see Table 2) indicates how a model fits with the data. The lower the deviance, the better the model fits.

\footnotetext{
${ }^{3}$ The values of these coefficients are reported in the Supporting Information: osf.io/3dkvb.
} 
Table 2. Effects of predictors of victimization on perceived collective victimhood: multilevel regression coefficients and model fit indicator

\begin{tabular}{|c|c|c|c|c|c|c|c|c|}
\hline & \multicolumn{2}{|c|}{ Empty model } & \multicolumn{2}{|c|}{ Death toll } & \multicolumn{2}{|c|}{ Family } & \multicolumn{2}{|c|}{ Identification } \\
\hline & B & SE & B & SE & B & SE & B & SE \\
\hline \multicolumn{9}{|l|}{ Individual-level predictor } \\
\hline Family member & & & & & $0.097^{* * *}$ & 0.019 & $0.090^{* * *}$ & 0.019 \\
\hline Country identification & & & & & & & $0.138^{\star \star \star}$ & 0.019 \\
\hline \multicolumn{9}{|l|}{ Societal-level predictor } \\
\hline Death toll WWI & & & $.208^{*}$ & 0.091 & $0.176^{*}$ & 0.080 & $0.187^{\star}$ & 0.083 \\
\hline Family mean & & & & & $0.142^{*}$ & 0.065 & $0.148^{*}$ & 0.066 \\
\hline Country identification mean & & & & & & & 0.037 & 0.069 \\
\hline Deviance (parameter) & 8056 & & 8052 & & 7987 & & 7929 & \\
\hline Random effects & Variance & & & & & & & \\
\hline Country & 0.27 & & 0.19 & & 1.14 & & 0.14 & \\
\hline Residual & 1.92 & & 1.92 & & 1.90 & & 1.85 & \\
\hline
\end{tabular}

Note: Bs are standardized regression coefficients

$p<0.1$;

${ }^{*} p<0.05$;

${ }^{* *} p<0.01$;

$* * * p<0.001$

We first tested an "empty model" allowing victimization to vary randomly across countries (left panel of Table 2). From this output, we computed the intraclass coefficient (.12). This indicated that $12 \%$ of the total variance in perceived collective victimhood related to WWI was because of the country and confirmed the relevance of relying on a multilevel model.

Next, we introduced the death toll related to WWI, which, in line with Hypothesis la reliably influenced perceived victimhood. The greater the death toll within a country, the greater the sense of WWIvictimization in that country. To interpret the unstandardized coefficient of .006, consider that an increase of 166 deaths per 1000 inhabitants translated into an increase of one point in the judgement of historical victimhood. ${ }^{4}$

Next, we introduced the death toll related to WWII in the model as a supplementary fixed effect (after excluding countries that did not participate in World War II). Indeed, it is plausible that people's sense of victimization associated to WWI may have been confused with the victimization produced by WWII. The impact of the number of casualties during WWII on the sense of victimization associated with WWI proved nonsignificant $(B=.001, S E=.004, t(1825)=.388, p=.704)$. We therefore ignored this variable from subsequent models.

Third, we examined whether the status of the country during WWI (i.e., belonging to the Entente, i.e., "winners" or the Central Powers, i.e., "losers") influenced victimization. As inclusion of this variable (dummycoded) did not exert any effect $(B=.30$, S.E. $=.248$, $t(2295)=1.20, p=.249)$, we did not consider it in the subsequent models either.

Fourth, to test Hypothesis $1 \mathrm{~b}$, we examined the role of the family level indicator of victimization. In order to do

\footnotetext{
${ }^{4}$ Given that an increase of 1 casualty per 1000 corresponds to .006 point on the victimhood scale, 166 casualties per 1000 (i.e., 1/.006) corresponds to 1 point.
}

so, we coded this value as -0.5 if participants had no family member involved in the war, .5 if they had and 0 if they responded that they did not know (Ns $=542$, 782 and 986 respectively). As with other level 1 predictors, we centred it within each country. We also included the mean of this variable at the country level as a predictor. It indeed allowed us to differentiate the "within-country" (level 1) effect of victimization from the "between country" (level 2) effect of victimization, which is also captured by the death toll.

Including these variables showed the following: People who reported having had a family member involved in WWI perceived more WWI-related victimhood than those who did not (in line with Hypothesis $1 b$ ). We even witnessed a marginal effect at the country level as indicated by the effect of the "Family mean" variable: Participants in countries whose members were more likely to report victims in their families tended to report greater victimhood even when controlling for the number of casualties and their individual level of family victimhood.

After having considered the impact of objective variables on perceived victimhood, we turn to the impact of a psychological variable: Country Identification. Again, we entered both identification centred per country and mean identification in the model. The results of this analysis are presented in the right panel of Table 2 . As can be seen, the effect of identification with the country on collective victimhood was strong (confirming Hypothesis 2) but it did not cancel the impact of the "objective" predictors.

\section{Predicting Acknowledgment of Inflicted Suffering}

There was wide between-country variation regarding the suffering inflicted on neighbouring countries as indicated by an intra-class correlation of .31 (see the empty model in the left panel of Table 3). From a 
Table 3. Effects of predictors of victimization on inflicted suffering to enemy countries: multilevel regression coefficients and model fit indicator

\begin{tabular}{|c|c|c|c|c|c|c|c|c|}
\hline & \multicolumn{2}{|c|}{ Empty model } & \multicolumn{2}{|c|}{ Death toll and family } & \multicolumn{2}{|c|}{$\begin{array}{l}\text { Perceived coll. victimhood } \\
\text { and identification }\end{array}$} & \multicolumn{2}{|c|}{ Interaction } \\
\hline & B & SE & B & SE & B & SE & B & SE \\
\hline \multicolumn{9}{|l|}{ Individual-level predictor } \\
\hline Family member & & & -0.002 & 0.026 & - & - & - & - \\
\hline Perceived coll. victimhood & & & & & $0.205^{* \star *}$ & 0.050 & $0.202^{* *}$ & 0.052 \\
\hline Country identification & & & & & $-0.105^{* * *}$ & 0.024 & $-0.118^{* * *}$ & 0.017 \\
\hline Perc. coll. vict. ${ }^{*}$ country identification & & & & & & & $-0.069^{* * *}$ & 0.017 \\
\hline \multicolumn{9}{|l|}{ Societal-level predictor } \\
\hline Death toll WWI & & & 0.020 & 0.122 & - & - & - & - \\
\hline Family mean & & & $0.247^{\star}$ & 0.104 & $0.175^{\star}$ & 0.077 & $0.193^{*}$ & 0.083 \\
\hline Perceived coll. victimhood mean & & & & & $0.201^{\star}$ & 0.082 & $0.193^{\circ}$ & 0.091 \\
\hline Country identification mean & & & & & $0.157^{*}$ & 0.065 & 0.116 & 0.071 \\
\hline Deviance (parameter) & 8758 & & 8700 & & 8483 & & 8475 & \\
\hline Random effects & Variance & & & & & & & \\
\hline Country & 1.12 & & 0.97 & & 1.13 & & 1.09 & \\
\hline Family member & & & 0.16 & & - & & - & \\
\hline Perceived coll. victimhood & & & & & 0.06 & & 0.07 & \\
\hline Country identification & & & & & 0.01 & & - & \\
\hline Residual & 2.63 & & 2.60 & & 2.32 & & 2.30 & \\
\hline
\end{tabular}

Note: Bs are standardized regression coefficients.

$p<0.1$.

${ }^{*} p<0.05$.

$* * p<0.01$.

$* * * p<0.001$.

descriptive point of view (see Table 1), it is worth noting that Austria, Germany and France acknowledged the highest suffering inflicted, and Finland and Serbia the lowest.

Next we entered indicators of victimization in the family as well as the death toll per country (second column of table 3). In this model, note that the slope for family level victimization varied randomly within county: a random slope was therefore included in addition to the intercept. However, only the mean level of family victimization at the country level had an effect on inflicted suffering: The greater the victimization, the greater the acknowledgment of inflicted suffering, contrary to Hypothesis 3.

In the next model, we included the measure of subjective WWI-related victimhood and national identification at the within-country (i.e., centred) level and let their slopes vary randomly. However, we did not include the death toll per country and the centred family variable, as these variables did not exert any significant effect in the previous model.

Again and contrary to Hypothesis 3, participants who considered that their country had been victimized were overall more likely to acknowledge that their country had inflicted suffering on other countries. This occurred both at the within-country and the between-country levels. Random slopes for inflicted suffering where included as well.

Next, to test Hypothesis 4, we examined whether national identification influenced acknowledgment of inflicted suffering. Indeed, at the within-country level, identification predicted acknowledgment negatively. This is consistent with Hypothesis 4. However, at level
2, the higher the mean level of identification within a country, the higher the acknowledgment of inflicted suffering. Figure 1 depicts this relation by plotting the residuals of the model (i.e., including all variables but level 2 national identification) as a function of national identification.

Finally, to test Hypothesis 5, we examined, in a new model, whether national identification moderated the impact of experienced suffering (victimhood) on inflicted suffering. In order to do so, we fitted the previous model but included the product of national identification and WWI-related victimization (within-group). As can be seen in Table 3, this interaction is highly significant. Figure 1 represents the effect of victimhood

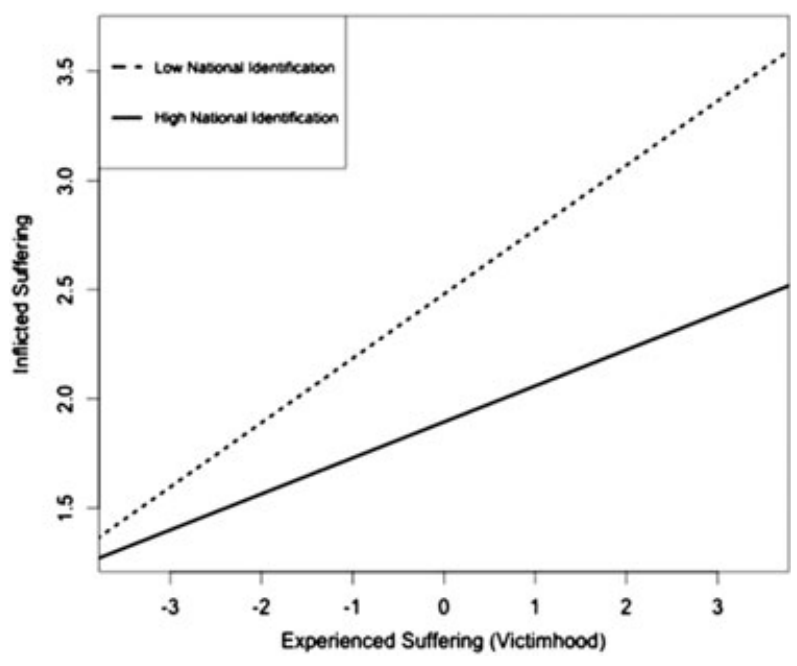

Fig. 1: Relation between perceived collective victimhood and inflicted sufferings as a function of the level of country identification 
Table 4. Effects of victimization variables on pacifism: multilevel regression coefficients and model fit indicator

\begin{tabular}{|c|c|c|c|c|c|c|}
\hline & \multicolumn{2}{|c|}{ Empty model } & \multicolumn{2}{|c|}{ Death toll and family } & \multicolumn{2}{|c|}{ Inflicted suffering } \\
\hline & B & SE & B & SE & B & SE \\
\hline \multicolumn{7}{|l|}{ Individual-level predictor } \\
\hline Family member & & & $-0.049^{*}$ & $0.020^{\circ}$ & $-0.046^{*}$ & 0.020 \\
\hline Inflicted suffering & & & & & $0.097^{*}$ & 0.036 \\
\hline \multicolumn{7}{|l|}{ Societal-level predictor } \\
\hline Death toll WWI & & & $0.166^{*}$ & 0.068 & $0.147^{*}$ & 0.067 \\
\hline Family mean & & & -0.062 & 0.056 & - & - \\
\hline Inflicted suffering mean & & & & & -0.056 & 0.060 \\
\hline Deviance (parameter) & 6176 & & 6130 & & 6035 & \\
\hline Random effects & Variance & & & & & \\
\hline Country & 0.06 & & 0.04 & & 0.04 & \\
\hline Inflicted suffering & & & & & 0.004 & \\
\hline Residual & 0.84 & & 0.84 & & 0.81 & \\
\hline
\end{tabular}

Note: Bs are standardized regression coefficients.

$p<0.1$.

${ }^{*} p<0.05$.

${ }^{* *} p<0.01$.

$* * * p<0.001$

on identification at one $S D$ below and above the withincountry mean. Within each country, there was a stronger association between perceived collective victimhood and inflicted victimhood among low than high identifiers. The direction of this interaction is consistent with Hypothesis 5 but rather than being more negative among low identifiers, the relation between experienced and inflicted suffering is less positive in this group.

\section{Pacifism}

Now that we have considered how objective and subjective factors may influence the sense of collective victimhood, we consider the role of these variables in pacifist attitudes. Again, we first fitted an empty model including only variations within countries. The intraclass correlation was .07 , indicating that the within-country variance was much higher than the between-country variance. Nonetheless, we proceeded as previously by adding death toll per country as well as the family victimization indicator. Results, displayed in Table 4, indicate that both societal-level and individual-level indicators of WWI-related victimization are linked to pacifism. In line with Elcheroth's findings (2006) and Hypotheses 6 and 7, we found that our two indicators of victimization predict current pacifism in opposite ways as a function of the level of analysis (collective and individual). As can be seen in Table 4, death toll by country was positively linked to pacifism (however marginally) whereas family victimization was negatively related to it. Note that the per-country mean for the family variable did not predict pacifism. We also fitted an augmented model including WWI status ("Entente" vs. "Central Powers"). However, WWI status did not predict pacifism over and above the previous variables and was therefore not included in subsequent models $(B=.17, S E=.13, p=.20)$.

Next, we examined whether WWI-related victimhood predicted pacifism when the family-level and country- levels of victimhood were taken into account. The answer to this question was negative for both the within-country effects and the between country effects (in both cases, $t<.20)$. This was inconsistent with Hypothesis 8. Again, these predictors were omitted from ulterior models.

Next, we considered whether the perception of acknowledgment of suffering inflicted to other countries affected pacifist attitudes. Again the effect of the mean level of perpetrated victimization was not significant but the within country effect was highly reliable, which was in line with Hypothesis 9: Participants who acknowledged that their country had victimized other countries during WWI were more likely to endorse pacifist attitudes than those who did not. Note that the slope of this variable varied across countries.

\section{Discussion}

Building on a large and diversified sample, the present study provides evidence that Europeans may still express a sense of collective victimhood associated with a 100-year old event. Second, individual differences in the perception of WWI-related victimhood are a function of actual experiences of victimization. These experiences have independent impacts if they are appraised at the collective (national) or individual (family stories) level. The results suggest that people's sense of victimization is constrained by actual experiences of victimization affecting their family or their country. Obviously, embellishment and collective imagination may colour memories of victimization in distinct hues, often exaggerating, sometimes minimizing, the group's painful experiences. But our findings suggest that history, understood here as facts about the group's victimization, constrains memory. This influence of history on memory is well illustrated by the effect sizes of objective indicators of victimization, that are often as large as the ones of subjective indicators such as national identification and acknowledgement of inflicted harm (see Tables 2-4). 
Among the factors that may define forms of victimhood in people's representations, we highlighted national identification and found, indeed, that individuals with a high level of identification reported more victimhood than those with a low level of identification. This is consistent with the assumption that collective victimization is presumed on a sense of collective identity (cf. Vollhardt, 2012). It also suggests that people's social identity may influence collective victimhood over and above their group (or family's) actual experience.

We also turned to the counterpart of victimhood, the acknowledgment of inflicted harm on others and found that, contrary to our expectations, it was positively related to a sense of victimization. Indeed, we presumed that the negative connotations associated with the perpetrator role would be incompatible with the more rewarding victim status. In the same vein, the active role of the perpetrator, a moral "agent" (cf. Gray \& Wegner, 2009) could have been viewed as incompatible with the passive role of the victim, a moral "patient".

Nonetheless, familiarity with the representations of World War I in Europe may render this finding less surprising. Contrary to World War II, which is often remembered as featuring clear heroes (e.g., American liberators) and villains (e.g., Nazis), WWI has been remembered, especially since the 1970s, as a "slaughterhouse" in which all nations both experienced and inflicted victimization (Todman, 2014). In this respect, they were both moral agents and moral patients. Further, it is plausible that, when carving a moral narrative of WWI, people do not categorize agents and patients in national terms. For example, after WWI, a dominant narrative emerged in which the central opposition is class-based: A common thread in WWI memory is that the war was organized by the elites at the expense of the less privileged (Todman, 2014, see also Bouchat et al., 2016). In this narrative, the disadvantaged social classes of all war mongering countries are the victims and the ruling classes the perpetrators.

Our analysis suggests that social representations (Moscovici, 1961), in the form of narratives (László, 2013), guide people's experiences of collective victimhood. However, these representations are maintained insofar as they fulfil needs related to the preservation of a satisfactory social identity (cf. Licata, Klein, \& Gély, 2007). How can the acknowledgment of having perpetrated harm on out-groups play such a role? Although speculative, several explanations are plausible. First, it is possible that victimhood somehow mitigates the moral responsibility for harm perpetration, and may even justify it, following the well-known logic of conflict escalation (Wohl \& Branscombe, 2005). For example, members of the Entente ("winners" of the war) could justify the harm inflicted on the Central Powers ("losers") by the aggression of Germany in August 1914. But, more fundamentally, lumping villains and victims together in the distant landscape of WWI may afford a

\footnotetext{
${ }^{5}$ We are indebted to Roger Giner-Sorolla for inspiring the use of the moral typecasting framework.
}

form of moral superiority to the inhabitants of today's Europe, in which the past warring nations are now at peace. Extending Festinger's classical work on interpersonal social comparison, Albert (1977) proposed a temporal comparison theory at an intra-individual level, that is, suggesting that individuals may seek to compare their current selves positively to their past selves. A narrative of collective redemption may play a similar role at a collective level: In this narrative, the current virtue of European countries can be contrasted with their past violence. Finally, acknowledging the harm done may in itself confer a sense of moral value (Brudholm, 2008). This is illustrated in the Belgian former Prime Minister's declaration suggesting that, by apologizing to the Rwandans for their responsibility in the Genocide, Belgians were among the most moral nations (see Rosoux, 2009, 2013).

In addition, we find support for the assumption that national identification is associated to a mitigation of the harm done to other groups. More interestingly, we observe that national identification moderates the relation between victimhood and acknowledgment of harm done. This suggests that high identifiers are more likely to see an opposition between victims and perpetrators with the in-group cast in the more rewarding role of victim rather than perpetrator. Thus, associating victims and perpetrators in a morally complex account of the war seems mainly possible for those who have not a strong national identity.

But when considering the country-level effects, we find that countries with the highest average level of identification in our sample are also those who are the most likely to acknowledge having inflicted suffering on others. Given the correlational nature of our findings, the direction of this relation is difficult to establish (e.g., having fought in WWl may have contributed to greater national identification). But at the very least, this finding shows that, consistent with the "narrative perspective", acknowledging victimization of others in a relatively distant past can be compatible with a high level of identification.

Finally, it is worth emphasizing that status as a "winner" or "loser" had little effect on collective victimhood or pacifism. During the inter-war years, very different lessons were drawn on both sides of this dividing line. For example, Germany witnessed a period of "brutalisation" and increased support for armed conflict (Mosse, 1990) whereas pacifism gained the upper hand especially in France and Britain (Becker, 2004). World War II transformed these attitudes and fostered a strong pacifist current in Germany as well (Mosse, 1990). Both sides suffered immensely from the war and the dividing lines of WWI have probably been superseded now by other oppositions (e.g., between East and West) as history has unfolded.

In line with Hypotheses 6 and 7 and supporting previous findings (Elcheroth, 2006), we observe distinct effects of group level and individual level indicators of victimization on pacifist attitudes: Thus, nations with more casualties tended to endorse more pacifist attitudes 
than those with fewer casualties. By contrast, participants who claimed having family members involved in WWI were less pacifist. In line with Elcheroth (2006), a tentative interpretation for these results would be that nations that faced many casualties, and a strong warrelated trauma, are particularly likely to have developed social representations valuing a peaceful coexistence. Our findings may be explained by the collective transmission of such representations across generations. But social representations operate at a societal level (Moscovici, 1961). At the family level, on the contrary, resentment against past enemies seems to remain present, and to fuel a more positive attitude towards war. Thus, we witness a complex legacy of victimization that can generate both brutalisation (Mosse, 1990) and pacifism. Policymakers and activists who have tried to implement reconciliation policies have had to grapple with the resistance of victimized communities (cf. Rosoux, 2013). The present study, while not questioning the legitimacy of pacifism as a desirable outcome of such policies, suggests that endorsing such attitudes can only be a long-term goal. That the legacy of victimization on pacifism can withstand four or five generations is indeed one of the most remarkable findings of this study even if, admittedly, the influence of family-level indicators is now much smaller than that of group-level victimization (cf. Table 4). It shows that the wounds that afflicted families during WWI have penetrated Europe for generations and can still influence contemporary young Europeans' outlook on peace and war.

Subjective experiences of victimhood did not predict pacifist attitudes (Hypothesis 8). The distinct lessons one can draw from victimization (e.g., peace or revenge) may have blurred the relationship between these two variables. By contrast, people who acknowledged the harm inflicted on other groups were also the most likely to express pacifist attitudes. This is consistent with Hypothesis 9 and highlights the existence of a "virtuous circle" between acknowledgment of harm done and reconciliation. The existence of this phenomenon has been previously highlighted by ČehajićClancy et al. (2011) who showed that acknowledgment of ingroup responsibility for out-group victimization was linked to an increased support for reparation policies to this out-group.

\section{Limitations}

While the present research offers new insights on the consequences of victimization a hundred years later, it is not devoid of important limitations. The most obvious one is its cross-sectional nature. Naturally, among the correlations we have identified, other causal relationships than those we have postulated are plausible. Especially, whereas we have considered national identification as a predictor of sense of collective victimhood, it may also be construed as an outcome of this feeling: Victimhood might be a building block in the construction of a national identity. In raising such a possibility, however, one should be cautious about levels of explanation (cf. Klein, 2009). Thus, victimized groups may develop a stronger national identity across generations. This is not necessarily true at a specific point in time for clearly identifiable individuals. By contrast, there are strong reasons to expect that national identification should predict a sense of victimhood at an individual level-given that national identification is a precondition for this sentiment to emerge.

A second limitation of the study resides in the composition of the sample on which our data were collected. It consisted of university students in social sciences (mainly psychology). The nature of the sources regarding WWI to which they have access differentiates them from a less educated population and may play a role in the present findings. As in most cross-cultural/national studies, the focus was made on comparability between the samples rather than on representativeness.

Third, the measures we used are often limited to a small number of items and sometimes only one. This is mainly because of the length of the questionnaire that addressed many aspects of the perception of WWI that are irrelevant to the focus of the present paper.

Further, our family-level indicator of victimization is not immune to biases. First, recollections may not be accurate. We took steps to enhance accuracy: Thus, participants who explicitly reported that they did not know of a relative were clearly differentiated from those who reported having none. Second, we asked them to specify the source of their knowledge and most of them reported that they had obtained such information through their grandparents who, presumably, had more directly reliable information having generally been in contact with persons with first-hand knowledge of the war. Nonetheless, a potential problem with our approach lies in the possibility that a third variable explains the relation between our family indicator and the outcome. For example, people who view war as an acceptable way to resolve conflicts (i.e., who are low in pacifism) may seek to justify these attitudes by downplaying the extent of victimization their family experienced when such a solution was used in the past. Hence, the conclusions of this study would certainly be strengthened if we could find indicators of family level victimization that do not rely on self-report, for example such as historical archives. Obviously, such a study would be extremely difficult to conduct with a large international sample such as the present one.

Second, the formulation of the question, which refers to a relative who "fought or died" leaves open the possibility that a relative was involved in the war, as a soldier, without being victimized by it, or that a relative was a civilian who was victimized without dying in the conflict. The last possibility can be viewed as a weakness of our indicator. Indeed, the way it was designed did not allow us to appraise the experience of civilian suffering that did not result in death. Although this problem cannot be eschewed, it is important to note that the majority of casualties of WWI were military (Prost, 2014). We also note that fighting in WW1 was often a victimizing experience for soldiers and their family even in the 
absence of wound or death. Nonetheless, more sensitive scales would certainly be welcome.

\section{Conclusion}

In his classic work on the memory of World War 1 in Europe, Mosse (1990) wonders whether "the transcendence of the war experience and death in war lead to (...) the domestication of modern war, its acceptance as a natural part of political and social life" (p. 11). The present study offers a partial answer to this question, as it suggests that the subjective experience of victimization associated with an event that occurred long before the participants' lifetime is sensitive to "objective" indicators of victimization at the personal and collective levels. It also evidences that this experience can be associated with an acknowledgment of the group's responsibility for the harm done to other countries. Further, we show that the experience of victimization predicts pacifist attitudes in opposite ways as a function of the level of analysis one considers. However, the impact of collective experiences of victimization, which are associated with more pacifist attitudes, seems to loom larger today than the family-level experiences of victimization, which drive more bellicose inclinations. Of the many lessons that revisiting the First World War can offer us, these are not the least valuable.

\section{Acknowledgements}

This research was conducted within the framework of COST Action IS 1205 "Social psychological dynamics of historical representations in the enlarged European Union.

\section{References}

Abbott, M. (2005). Technology of World War I and the soldiers who experienced it. (Unpublished senior thesis). University of North Carolina, Asheville.

Albert, S. (1977). Temporal comparison theory. Psychological Review, 84(6), 485-503. http://dx.doi.org/10.1037/0033295X.84.6.485

Assman, A., \& Conrad, S. (2010). Memory in a global age: Discourses, practices and trajectories. London: Palgrave.

Audoin-Rouzeau, S., \& Becker, A. (2000). 14-18, retrouver la guerre [14-18, Retrieve the War] (pp. 39-44). Paris: Gallimard.

Barkan, E. (2000). The guilt of nations: Restitution and negotiating historical injustices. New York: Norton.

Bar-Tal, D. \& Antebi, D. (1992). Beliefs about negative intentions of the world: A study of the Israeli siege mentality. Political Psychology, 13(4), 633-645. http://dx.doi.org/ 10.2307/3791494

Bar-Tal, D., Chernyak-Hai, L., Schori, N., \& Gundar, A. (2009). A sense of self-perceived collective victimhood in intractable conflicts. International Review of the Red Cross, 91(874), 229-258. http://dx.doi.org/10.1017/S1816383109990221

Bates, D., Mächler, M., Bolker, B., \& Walker, S. (2014). Fitting linear mixed-effects models using lme4. arXiv preprint arXiv:1406.5823.
Baumeister, R. E., Exline, J. J., \& Sommer, K. L. (1998). The victim role, grudge theory, and two dimensions of forgiveness. In E. L. Worthington Jr. (Ed.), Dimensions of forgiveness (pp. 79-104). Radnor, PA: Templeton Foundation Press.

Baumeister, R. F., \& Hastings, S. (1997). Distortions of collective memory: How groups flatter and deceive themselves. In J. W. Pennebaker, D. Páez, \& B. Rimé (Eds.), Collective memory of political events: Social psychological perspectives (pp. 277-293). Hillsdale, NJ: Lawrence Erlbaum.

Becker, A. (2004). Messianismes, héritage de la violence, totalitarisme [Messianisms, legacy of violence, totalitarism]. In S. Audouin-Rouzeau, \& J.-J. Becker (Eds.), Encylcopédie de la Grande Guerre [Encyclopedia of the Great War] (pp. 1151-1162). Paris: Bayard.

Bieber, F. (2002). Nationalist mobilization and stories of Serb suffering: The Kosovo myth from 600th anniversary to the present. Rethinking History, 6(1), 95-1 10. http://dx.doi.org/ $10.1080 / 136425200110112137$

Bizumic, B., Stubager, R., Mellon, S., Van der Linden, N., Iyer, R., \& Jones, B. M. (2013). On the (in) compatibility of attitudes toward peace and war. Political Psychology, 34(5), 673-693. http://dx.doi.org/10.1111/pops.12032

Bobowik, M., Paez, D., Liu, J. H., Licata, L., Klein, O., \& Basabe, N. (2014). Victorious justifications and criticism of defeated: Involvement of nations in world wars, social development, cultural values, social representations of war, and willingness to fight. International Journal of Intercultural Relations, 43, 60-73. http://dx.doi.org/10.1016/j. ijintrel.2014.08.013

Bouchat, P., Licata, L., Rosoux, V., Allesch, C., Ammerer, H., Bilewicz, M., ... Klein, O. (2016). World War what? Toward a homogenization of the representations of the Great War in Europe. Manuscript submitted for publication.

Branscombe, N. R., \& Doosje, B. (2004). Collective guilt: International perspectives. Cambridge, UK: University Press.

Brock, P., \& Young, N. (1999). Pacifism in the twentieth century. Syracuse, NY: Syracuse University Press.

Brooks, N. (1999). When sorry isn't enough: The controversy over apologies and reparations for human injustice. New York: New York University Press.

Brudholm, T. (2008). Resentment's virtue: Jean Améry and the refusal to forgive. Philadelphia, PA: Temple University Press.

Cabanes, B., \& Piketty, G. (2009). Retour à l'intime: Au Sortir de la Guerre [Return to the intimate: After the War]. Paris: Tallandier.

Čehajić, S., Brown, R., \& González, R. (2009). What do I care? Perceived ingroup responsibility and dehumanization as predictors of empathy felt for the victim group. Group Processes $\theta$ Intergroup Relations, 12(6), 715-729. http://dx.doi. org/10.1177/1368430209347727

Čehajić-Clancy, S., Effron, D. A., Halperin, E., Liberman, V., \& Ross, L. D. (2011). Affirmation, acknowledgment of ingroup responsibility, group-based guilt, and support for reparative measures. Journal of Personality and Social Psychology, 101 (2), 256-270. http://dx.doi.org/10.1037/a0023936

Chaumont, J.-M. (1997). La Concurrence des victimes. Génocide, identité, reconnaissance [The victims' competition: Genocide, identity, acknowledgment]. Paris: La Découverte.

Cohrs, J. C., \& Nelson, L. L. (2012). Militaristic attitude. In D. J. Christie (Ed.), Encyclopedia of peace psychology (pp. 636-641), 2 Eq-Po;. Malden, MA: Wiley-Blackwell. 
Cohrs, J. C., \& O'Dwyer, E. (in press). "In the minds of men..." - Social representations of war and military intervention. In P. L. Hammack (Ed.), The Oxford handbook of social psychology and social justice. New York, NY: Oxford University Press.

Davoine, F., \& Gaudillière, J. M. (2004). Histoire et trauma. La folie des guerres [History and trauma: The madness of wars]. Paris: Stock.

De Vos, L., \& Keymeulen, H. (1989). Een definitieve afrekening met de $80 \%$-mythe? Het Belgisch Leger (1914-1918) en de sociale en numerieke taalverhouding onder de gesneuvelden van lagere rang [A final reckoning with the 80\%-myth? The Belgian army (1914-1918) and the social and numerical linguistic ratio among the fallen in action]. Revue Belge d'Histoire Militaire, 27, 589-612.

Doosje, B., Branscombe, N. R., Spears, R., \& Manstead, A. S. (1998). Guilty by association: When one's group has a negative history. Journal of Personality and Social Psychology, 75(4), 872-886. http://dx.doi.org/10.1037/ 0022-3514.75.4.872

Durkheim, E. (1897/1987). Suicide (J. A. Spaulding \& G. Simpson, Trans.). London, UK: Routledge \& Kegan Paul Ltd.

Elcheroth, G. (2006). Individual-level and community-level effects of war trauma on social representations related to humanitarian law. European Journal of Social Psychology, 36(6), 907-930. http://dx.doi.org/10.1002/ejsp.330

Enders, C. K., \& Tofighi, D. (2007). Centering predictor variables in cross-sectional multilevel models: A new look at an old issue. Psychological Methods, 12(2), 121-138. http:// dx.doi.org/10.1037/1082-989X.12.2.121

Gallagher, E. (2015). 'The first casualty when war comes is truth': Neglected atrocity in First World War Australian memory. History in the Making, 4(1), 54-64. http:// historyitm.org/index.php/hitm/article/view/322/78

Gray, K., \& Wegner, D. (2009). Moral typecasting. Divergent perception of moral agents and moral patients. Journal of Personality and Social Psychology, 96(3), 505-520. http://dx. doi.org/10.1037/a0013748

Halperin, E., Bar-Tal, D., Nets-Zehngut, R., \& Drori, E. (2008). Emotions in conflict: Correlates of fear and hope in the Israeli-Jewish society. Peace and Conflict: Journal of Peace Psychology, 14(3), 233-258. http://dx.doi.org/10.1080/ 10781910802229157

Hammack, P. L. (2009). Exploring the reproduction of conflict through narrative: Israeli youth motivated to participate in a coexistence program. Peace and Conflict: Journal of Peace Psychology, 15(1), 49-74. http://dx.doi.org/ $10.1080 / 10781910802589923$

Hilton, D. J., \& Liu, J. H. (2008). Culture and inter-group relations. The role of social representations of history. In R. Sorrentino, \& S. Yamaguchi (Eds.), The handbook of motivation and cognition: The cultural context (pp. 343-368). New York: Guilford.

Klar, Y., Schori-Eyal, N., \& Klar, Y. (2013). The “Never Again” state of Israel: The emergence of the Holocaust as a core feature of Israeli identity and its four incongruent voices. Journal of Social Issues, 69(1), 125-143. http://dx.doi.org/ $10.1111 /$ josi.12007

Klein, O., (2009). From Utopia to Dystopia: Levels of explanation and the politics of social psychology. Psychologica Belgica. 49(2-3), pp.85-100. http://doi.org/10.5334/pb-49-2-3-85
Klein, O., Licata, L., \& Pierucci, S. (2011). Does group identification facilitate or prevent collective guilt about past misdeeds? Resolving the paradox. British Journal of Social Psychology, 50(3), 563-572. http://dx.doi.org/10.1111/ j.2044-8309.2011.02028.x

Klein, O., Licata, L., Van der Linden, N., Mercy, A., \& Luminet, O. (2012). A waffle-shaped model for how realistic dimensions of the Belgian conflict structure collective memories and stereotypes. Memory Studies, 5(1), 16-31. http://dx.doi.org/10.1177/1750698011424028

Kuznetsova, A., Borckhoff, P. B., \& Christensen, R. H. B. (2015). Package 'LmerTest' version 2.0-29. Downloaded from the internet at https://cran.r-project.org/web/packages/lmerTest/index.html

László, J. (2013). Historical tales and national identity: An introduction to narrative social psychology. London: Routledge.

Lerner, M. J. (1998). The two forms of belief in a just world: Some thoughts on why and how people care about justice. In L. Montada, \& M. J. Lerner (Eds.), Responses to victimizations and belief in a just world (pp. 247-269). New York, London: Plenum Press.

Licata, L., Klein, O., \& Gély, R. (2007). Mémoire des conflits, conflits de mémoires: une approche psychosociale et philosophique du rôle de la mémoire collective dans les processus de réconciliation intergroupe [Memory of the Conflicts, Conflicts of Memories: A psychosocial and philosophical approach of the role of collective memory in intergroup reconciliation processes]. Social Science Information, 46(4), 563-589. http://dx.doi.org/10.1177/ 0539018407082593

Lind, J. (2008). Sorry states: Apologies in international politics. Ithaca: Cornell University Press.

Liu, J. H., Goldstein-Hawes, R., Hilton, D. J., Huang, L. L., Gastardo-Conaco, C., Dresler-Hawke, E., Pittolo, F., Hong, Y. Y., Ward, C., Abraham, S., Kashima, Y., Kashima, E., Ohashi, M., Yuki, M., \& Hidaka, Y. (2005). Social representations of events and people in world history across 12 cultures. Journal of Cross-Cultural Psychology, 36(2), 171-191. http://dx.doi.org/10.1177/0022022104272900

Lucas, E. (1932). Reading, writing and remembering, a literary record. London: Methuen.

McCullough, M. E., Kurzban, R., \& Tabak, B. A. (2013). Cognitive systems for revenge and forgiveness. Behavioral and Brain Sciences, 36(1), 1-15. http://dx.doi.org/10.1017/ S0140525X11002160

Morin, E. (1987). Penser l'Europe [Thinking Europe]. Paris: Gallimard.

Moscovici, S. (1961). La psychanalyse, son image, son public. Paris: Presses Universitaires de France.

Mosse, G. L. (1990). Fallen soldiers: Reshaping the memory of the world wars. Oxford, UK: Oxford University Press.

Noor, M., Brown, R., Gonzalez, R., Manzi, J., \& Lewis, C. A. (2008). On positive psychological outcomes: What helps groups with a history of conflict to forgive and reconcile with each other?. Personality and Social Psychology Bulletin, 34(6), 819-832. http://dx.doi.org/10.1177/ 0146167208315555

Noor, M., Brown, R., \& Prentice, G. (2008). Precursors and mediators of intergroup reconciliation in Northern Ireland: A new model. British Journal of Social Psychology, 47(3), 481-495. http://dx.doi.org/10.1348/014466607X238751 
Noor, M., Shnabel, N., Halabi, S., \& Nadler, A. (2012). When suffering begets suffering the psychology of competitive victimhood between adversarial groups in violent conflicts. Personality and Social Psychology Review, 16(4), 351-374. http://dx.doi.org/10.1177/1088868312440048

Overmans, R. (2004). Kriegsverluste [War losses]. In G. Hirschfeld, G. Krumeich, \& I. Renz (Eds.), Enzyklopädie Erster Weltkrieg [Encyclopedia of World War]. Paderborn: Schöningh.

Paez, D., Liu, J. H., Techio, E., Slawuta, P., Zlobina, A., \& Cabecinhas, R. (2008). "Remembering" World War II and willingness to fight sociocultural factors in the social representation of historical warfare across 22 societies. Journal of Cross-Cultural Psychology, 39(4), 373-380. http:// dx.doi.org/10.1177/0022022108316638

Pennekamp, S. F., Doosje, B., Zebel, S., \& Fischer, A. H. (2007). The past and the pending: The antecedents and consequences of group-based anger in historically and currently disadvantaged groups. Group Processes and Intergroup Relations, 10(1), 41-55. http://dx.doi.org/10.1177/ 1368430207071339

Pettigrew, T. F. (2006). The advantages of multilevel approaches. Journal of Social Issues, 62(3), 615-620. http:// dx.doi.org/10.1111/j.1540-4560.2006.00477.x

Prost, A. (2014). War losses. In U. Daniel, P. Gatrell, O. Janz, H. Jones, J. Keene, A. Kramer, \& B. Nasson (Eds.), 19141918-Online international encyclopedia of the First World War. Berlin: Freie Universität Berlin. http://dx.doi.org/ 10.15463/ie1418.10271

Prost, A., \& Winter, J. (2004). Penser la Grande Guerre: Un essai d'historiographie [Thinking the Great War: A historiographical essay]. Paris: Seuil.

Rice, C. A., \& Benson, J. F. (2005). Hungering for revenge: The Irish famine, the troubles and shame-rage cycles, and their role in group therapy in Northern Ireland. Group Analysis, 38(2), 219-235. http://dx.doi.org/10.1177/ 0533316405052380

Ricoeur, P. (2004). Memory, history, forgetting. Chicago, IL: University of Chicago Press.

Riedlmayer, A. (1993). A brief history of BosniaHerzegovina. As compiled for the Bosnian Manuscript Ingathering Project. Retrieved from http://www.kakarigi. net/manu/briefhis.html

Rimé, B., Bouchat, P., Klein, O., \& Licata, L. (2015). When collective memories of victimhood fade: Generational evolution of intergroup attitudes and political aspirations in Belgium. European Journal of Social Psychology, 45(4), 515-532. http://dx.doi.org/10.1002/ejsp.2104

Roccas, S., Klar, Y., \& Liviatan, I. (2006). The paradox of group-based guilt: Modes of national identification, conflict vehemence, and reactions to the in-group's moral violations. Journal of Personality and Social Psychology, 91(4), 698-711. http://dx.doi.org/10.1037/0022-3514.91.4.698

Rosoux, V. (2004). Human rights and the 'work of memory' in international relations. International Journal of Human Rights, 3, 159-170. http://dx.doi.org/10.1080/ 1475483042000210694

Rosoux, V. (2009). La politique africaine de la Belgique: entre génuflexion et injonctions [African Policy of Belgium: Between Genuflection and Injunctions]. Raison publique, 10, 67-80.
Rosoux, V. (2013). Is reconciliation negotiable? International Negotiation, 18, 471-493. http://dx.doi.org/10.1163/ 15718069-12341266

Schori-Eyal, N., Halperin, E., \& Bar-Tal, D. (2014). Three layers of collective victimhood: Effects of multileveled victimhood on intergroup conflicts in the Israeli-Arab context. Journal of Applied Social Psychology, 44(12), 778-794. http://dx.doi.org/10.1111/jasp.12268

Snijders, T. B., \& Bosker, R. R. (1999). Multilevel analysis: An introduction to basic and advanced multilevel modeling. London: Sage.

Staub, E. (2006). Reconciliation after genocide, mass killing or intractable conflict: Understanding the roots of violence, psychological recovery and the steps toward a general theory. Political Psychology, 27, 867-894. http://dx.doi.org/ 10.1111/j.1467-9221.2006.00541.x

Staub, E., \& Bar-Tal, D. (2003). Genocide, mass killing and intractable conflict: Roots, evolution, prevention and reconciliation. In D. O. Sears, L. Huddy, \& R. Jervis (Eds.), Oxford handbook of political psychology (pp. 710-751). New York: Oxford University Press.

Todman, D. (2014). The Great War: Myth and memory. London: Bloomsbury.

Todorov, T. (1995). Les abus de la mémoire [The abuse of memory]. Paris: Arléa.

Vollhardt, J. (2012). Collective victimization. In L. R. Tropp (Ed.), Oxford handbook of intergroup conflict (pp. 136-157). New York, NY: Oxford University Press.

Vollhardt, J. R. (2010). Victim consciousness and its effects on inter-group relations-A double-edged sword? (Unpublished doctoral dissertation). University of Massachusetts, Amherst, MA.

Vollhardt, J. R., Mazur, L. B., \& Lemahieu, M. (2014). Acknowledgment after mass violence: Effects on psychological well-being and intergroup relations. Group Processes $\theta$ Intergroup Relations, 17, 306-323. http://dx.doi.org/ $10.1177 / 1368430213517270$.

Warner, R. H., Wohl, M. J., \& Branscombe, N. R. (2014). When do victim group members feel a moral obligation to help suffering others? European Journal of Social Psychology, 44(3), 231-241. http://dx.doi.org/10.1002/ejsp.2010

Winter, J. (2004). Victimes de la guerre: Morts, blessés et invalides [Victims of the war: Dead, wounded, handicapped]. In S. Audouin-Rouzeau, \& J.-J. Becker (Eds.), Encylcopedie de la Grande Guerre (pp. 1075-1085). Paris: Bayard.

Wohl, M. J. A., \& Branscombe, N. R. (2005). Forgiveness and collective guilt assignment to historical perpetrator groups depend on level of social category inclusiveness. Journal of Personality and Social Psychology, 88(2), 288-303. http:// dx.doi.org/10.1037/0022-3514.88.2.288

Wohl, M. J., Branscombe, N. R., \& Klar, Y. (2006). Collective guilt: Emotional reactions when one's group has done wrong or been wronged. European Review of Social Psychology, 17(1), 1-37. http://dx.doi.org/10.1080/ 10463280600574815

World War 1 casualties (n.d) In Wikipedia. Retrieved from https://en.wikipedia.org/wiki/World_War_I_casualties

World War 1I casualties (n.d) In Wikipedia. Retrieved from https://en.wikipedia.org/wiki/World_War_II_casualties 